\title{
AN EMPIRICAL STUDY ON DESIGN, DEVELOPMENT AND ACCESSIBILITY OF SUBJECT GATEWAY FOR ENGINEERING RELATED SUBJECTS
}

\author{
S. RAJENDRAN ${ }^{1}$ \& S. SRINIVASARAGAVAN ${ }^{2}$ \\ ${ }^{1}$ Research Scholar, Assistant Librarian, Government Law College, Madurai, Tamil Nadu, India \\ ${ }^{2}$ Professor \& Head, Department of Library \& Information Science, Bharathidasan University, \\ Tiruchirappalli, Tamil Nadu, India
}

\begin{abstract}
Subject Gateway is an organized collection of resources on a given subject along with a retrieval mechanism. This essentially means that the scope of the search domain is well defined and limited to a subset of what exists in general. In the simplest form, the resources may be made available as a structured hyperlinked directory. A subject directory is a service that offers a collection of links to web sites, organized into subject categories. The value of subject directories is that you can browse by predetermined subject headings or categories, and that website has been classified by people rather than computers. Yahoo is a classic example of a subject directory. It categorizes the universe of knowledge into several subject headings. These are further broken down into sub-headings and links are given to the corresponding web pages. The target audience is hence very generic.

KEYWORDS: Subject Gateway, Engineering \& Web Sites
\end{abstract}

Received: Jul 27, 2017; Accepted: Aug 16, 2017; Published: Aug 28, 2017; Paper Id: IJISMRDOCT20171

\section{INTRODUCTION}

The Information technology has made many advances over the years, with the most rapid ones coming recently, from Gutenberg's printing press to e-publishing. One might think that technology is making it easier for us to organize and store information, has made access and retrieval easier; however, it is not a straightforward case. Advancing technology has created a whole new problem information boom. Technological advances have made it easier and faster to analyze, collect, abstract, index, search, and use data and information. But the information may be scattered, not only in several different databases, but also on completely different systems, some, of which users may not be able to access. If information professionals find it difficult, then for users it is nearly impossible. So, to arrest this titanic problem, the concept of "Subject Gateways" has emerged. The subject gateways are engaged in responding to the challenges of "resource discovery", in a fast developing internet environment in the early and mid 1990s

The principal historical methods and quality standards established during the last one and a half centuries by the science of history can be adapted to the online world of historical content. However, new criteria for online historical content still have to be established for "secondary aspects" such as technical form and structure of content, metadata and linking. Only if such standards are well-established inside the community of online history, an efficient coverage of the online historical information space can be established and potentially leverage a participation in the vision of the Semantic Web for the further future. Subject gateways are already familiar features of the world information landscape and fulfill a useful role in directing Internet users to quality 
information. These are online service and sites that provide searchable and brows able catalogue of Internet base resources. A Subject gateway is a web site that provides searchable and browses able access to online resources focused around a specific subject. It provides a resource discovery mechanism for accessing a collection of high quality evaluated resources identified to support research in a particular subject discipline.

\section{CONCEPT OF GATEWAYS}

Moffat describes the establishment of the gateways as "a process of identification, filtering, description, classification and indexing before they are added to databases which is freely available via a WWW. Gateways are the Internet search tools to help people find resources on the Internet. Gateways offer linked collections of Internet resources via a database of resource description. This can be: Browsed - according to broad classification Searched -through index Quality controlled - due to selection Thus, it can be said that the gateways are "a gathering place of discipline specific resources."

A subject directory is a service that offers a collection of links to web sites, organized into subject categories. The value of subject directories is that you can browse by predetermined subject headings or categories, and that website has been classified by people rather than computers. Yahoo is a classic example of a subject directory. It categorizes the universe of knowledge into several subject headings. These are further broken down into sub-headings and links are given to the corresponding web pages. The target audience is hence very generic.

\section{IMPORTANCE OF GATEWAYS}

A gateway acts as a sort of interpreter which converts design specific protocols, information structures and presentation specific details of one system into corresponding counterparts of the other system. Gateways allow you to view the whole complexity of the information contents of different representations in a unified way as one single information system. Much interesting data, such as online telephone directories, railway time schedules and many other collections of information are of very dynamic natures that require robust distributed database management systems.

The access mechanisms and the presentation capabilities of distributed database systems and other third-party information systems are often complicated and specified for a single hardware platform, requiring extensive end-user training. Traditionally, access to such databases has been mostly textually or menu-driven. Application programmers usually had the possibility to enhance the interfaces based on an Application Programmers Interface.

\section{ENGINEERING SCIENCE}

Engineering science refers to the study of the combined disciplines of physics, mathematics and engineering, particularly computers, nuclear, electrical, electronic, mechanical, and Biomedical engineering. By focusing on the scientific method as a rigorous basis, it seeks ways to apply, design and develop new solutions in engineering. Engineering science degrees are respected academic degrees awarded in many countries. It can be taught at the undergraduate and postgraduate level and is often designed as an honors program at some universities due to the rigorous nature of the academic curriculum which covers a wide spectrum of scientific disciplines.

\section{REVIEW OF LITERATURE}

A review of current literature pertaining to Subject Gateways was undertaken using relevant electronic databases, periodical databases, Internet periodicals and library catalogues. 
Feng et.al (2012) has explained in order to promote the development and application of family intelligent network technology, in this paper, a design of intelligent family network based on the distributed control system is introduced. The network communication and control structure of systems make use of a distributed control system, the gateway makes use of construction of embedded systems, and remote control design makes use of browser/server to achieve. The programming provides stronger advancement, creation, flexibility and reliability with great research significance and application value.

Han et.al (2011) has explained that pattern data are fundamental to understanding transcriptional regulatory networks and the biological significance of such networks. For Caenorhabditis elegant, expression pattern analysis of transcription factor genes, with cellular resolution, typically involves generation of transcription factor gene/reporter gene fusions. This is followed by the creation of C. Elegance strains transgenic for, and determination of expression patterns driven by, these fusions. Physiologically relevant regulatory relationships between transcription factors are both inferred from their expression patterns, in combination with protein-DNA interaction data, and evidenced from alterations of expression patterns when networks are disturbed.

Wang (2011) in their article is to draw the attention of all sectors of the society to subject information gateway construction and guide the experts in computer science and library and information science to attach importance to the utilization and exploitation of key information techniques of subject information gateway service. The Internet survey and literature investigation are research methods of this article. The conclusion shows that people don't concern about utilization of subject information gateway because of the lack of in-depth exploitation.

\section{STATEMENT OF THE PROBLEM}

The present study is to analyze the design, content analysis and accessibility of subject gateway for Engineering Science. This study deals with the use and accessibility of engineering sciences subject gateway services from the patron point of view. There is a need to assess the extent of requirements development, execution, and content analysis of gateways. Further, there is no union catalogue of any other location tools to locate the serial holdings of the engineering sciences information which are essential for research scholars, faculty members, scientists and students. Since on research has been conducted in this area, it was decided to undertake a study on the subject gateways to share the Meta data within a single domain for a particular field, occupation or industry.

\section{OBJECTIVE OF THE STUDY}

The main objective of the engineering subject gateway is to fulfill the information requirements for the faculty members, researchers and students in the engineering and allied courses institutions in Tamil Nadu. It is objectives are:

- To identify and understand the using subject gateways of Engineering.

- To analysis the importance of web services of Engineering

- For analysis the current use of gateways in Engineering.

- To study the availability, accessibility and utilization of subject gateway information.

- To collect the major useful subject gateways in the Engineering field. 


\section{SCOPE AND METHODOLOGY}

The present study analyses on available subject gateways, in engineering sciences subjects offered in engineering institutions. Engineering science is a major branch of study related to many interrelated components such as civil engineering, mechanical engineering, computer science; engineering, biomedical engineering, Instrumentation Engineering, Electrical engineering and Electronics engineering etc. and informations are both in printed and e- sources. For the convenience of the study, the researcher has taken the available subject gateways and analysis the structure, utilization and facture requirements to improve the subject gateway from the user point of view.

\section{Engineering Subject Gateway}

Engineering subject gateway is developed to provide easy accessing of required information on the specialized web through a common user interface. The user experience is an important element in the use of subject gateways in which, user can access all information in connection with their subject areas. The engineering subject gateway contains information about e-journals, e-books, online databases, theses, dissertation, conferences, funding agencies, patents, standards etc.

\section{Important Engineering Gateways}

\section{General Engineering}

Efunda: http://www.efunda.com/home.cfm

EEVL: http://www.eevl.ac.uk/engineering/index.htm

GrayLIT Network: https://www.osti.gov/graylit

MatWeb: http://www.matweb.com/

E-Books: https://www.nap.edu/topic/284/engineering-and-technology

NASA Technical Reports Server (NTRS): https://ntrs.nasa.gov/

OSTI e-Prints https: //www.osti.gov/home/RETIRED/eprints.html

Engineering Libraries on the Web: http://web.library.uiuc.edu/grainger/resrc/englib/default.asp

Engineering Jobs: http://www.engineeringjobs.com/

Conferences and Events: http://dir.yahoo.com/Science/engineering/events/

Periodic Table of the Elements: http://www.webelements.com/

Unit Conversion Tool: http://www.convertauto.com/

Aerospace Industries Association: http://www.aia-aerospace.org/

Aerospace Industries Association of Canada: http://www.aiac.ca/

AIAA: http://www.aiaa.org/

European Space Agency: http://www.esa.int/esaCP/index.html

National Space Society: http://www.nss.org/ 
Subject Gateway for Engineering Related Subjects

Royal Aeronautical Society: http://www.raes.org.uk/

Advanced Topics in Aerodynamics: http://aerodyn.org/

Aerospaceweb.org: http://www.aerospaceweb.org/

Basics of Space Flight: http://www.jpl.nasa.gov/basics/

Encyclopaedia Astronautica: http://www.astronautix.com/

Find it @ NASA: http://search.nasa.gov/nasasearch/search/advSearch.jsp

NASA Documents Online: http://www.hq.nasa.gov/office/hqlibrary/find/nasadoc.htm

\section{Biomedical}

AAAShttp: //www.aaas.org/

Association for the Advancement of Medical Instrumentation (AAMI)

http://www.aami.org/

The American Institute of Biological Sciences (AIBS): http://www.aibs.org/

American Society of Biomechanics: http://asb-biomech.org/

Biomedical Engineering Societyhttp: //www.bmes.org/

Human Factors and Ergonomics Societyhttp: //hfes.org/

International Society of Biomechanicshttp: //www.isbweb.org/

Institute of Industrial Engineers (IIE): http://www.iienet.org/

National Academy of Sciences (NAS): http://www.nas.edu/

Society for Biomaterialshttp: //www.biomaterials.org/

The Whitaker Foundationhttp: //www.whitaker.org/

Supporting research and education in biomedical engineering.

Biomaterials Properties Databasehttp: //www.lib.umich.edu/dentlib/Dental_tables/toc.html

BMEsource.orghttp: //bmesource.org/

Directory of Published Proceedings: http://www.interdok.com/dopp/index.cfm

EEVL -- Edinburgh Electronic Virtual Library -- Bioengineering

http://www.eevl.ac.uk/engineering/eng-browse- page.htm

Gray's Anatomy of the Human Bodyhttp://bartleby.com

Patents in the Knowledge Based Economy: http://books.nap.edu/openbook/0309086361/html/

Annual Reviews: http://arjournals.annualreviews.org/ 
BMEnet: The Biomedical Engineering Network http://www.bmenet.org/BMEnet/

Merck Manual of Medical Information: Home Edition.

http://www.merck.com/pubs/mmanual_home

Yahoo! Biomedical Engineering

http://dir.yahoo.com/Science/Engineering/Biomedical_Engineering/

The Biomedical Engineering Network: http://www.bmenet.org/

Bioethics.net: http://bioethics.net/

Biomedical Information Resources \& Services - by Subject: http://www.mic.ki.se/Other.html

\section{Chemical Engineering:}

ACSWeb from the American Chemical Society http://wash30.acs.org:8001/Welcome.html

ASEE Clearinghouse for Engineering Education http://www.asee.org/index.html

American Institute of Chemical Engineers Web http://www.aiche.org/

American Physical Societyhttp://www.aps.org/

American Vacuum Society http://www.vacuum.org/

Engineering Foundation http://www.engfnd.org/engfnd/

Institution of Chemical Engineers http://icheme.chemeng.ed.ac.uk/

The Electrochemical Society, Inc. http://www.electrochem.org/

Chemical Engineeringhttp://www.che.ufl.edu/www-che/

Periodic Table of the Elementshttp://www.webelements.com/

www.chemindex.org http://www.chemdex.org/index

\section{Electrical Engineering}

ARPAhttp://www.chemdex.org/index.

Institute of Electrical and Electronics Engineers, Inc. (IEEE)http://www.ieee.org/

Institution of Electrical Engineers (IEE)http://www.iee.org.uk/

Instrumentation and Control Engineering Societyhttp://www.icesociety.org/

National Industrial Information Infrastructure Protocols (NIIIP) Consortiumhttp://www.niiip.org/

SIGDA: the ACM Special Interest Group on Design Automationhttp://kona.ee.pitt.edu/

The EEEL at NISThttp://www.eeel.nist.gov/

VTT Electronics http://www.ele.vtt.fi/ 
Digitallab-EE Tutorial \& Directoryhttp://digitallab.uni.cc/

EE Times Networkhttp://www.eetimesnetwork.com/

Electrical Engineering page on EINet Galaxy http://galaxy.einet.net/galaxy/Engineering-and-Technology/ Electrical-Engineering.html

Electronics resources websitehttp://www.electronicsee.com/

Electronics Web - Information resource for the Electronic Engineering industryhttp://www.electronicsweb.com/

AVEL: Australasian Virtual Engineering Libraryhttp://avel.edu.au/

\section{Material Science}

Department of Defense (AMPTIAC)http://ammtiac.alionscience.com/

ASM International: The Materials Information Societyhttp://asmcommunity.asminternational.org/portal/site/asm/ Center for Functional Nanomaterials, Brookhaven National Laboratory http://www.cfn.bnl.gov/

International Association of Nanotechnology: http://www.ianano.org/

Materials Science and Engineering (MSE)http://www.crc4mse.org/

Materials Science and Engineering Laboratory: http://www.msel.nist.gov/ Network for Computational Nanotechnologyhttp://www.ncn.purdue.edu/home/

Society for the Advancement of Material and Process Engineering (SAMPE)

http://www.sampe.org/

A+ Materials Science and Engineering Glossary of Terms

http://www.justinline.com/glossary/

AZoM.com http://www.azom.com/default.asp

BUBL: Materials science

http://www.utsi.edu/library/bubl.ac.uk/link/m/materialsscience.htm

Materials Digital Library: http://www.matdl.org/

Materials Science Resources on the Webhttp://www.istl.org/02-spring/internet.html

Matwebhttp://www.matweb.com/index.asp?ckck=1

Materials Research Center at the University of Chicago

http://mrsec.uchicago.edu/index.html

nanoHUBhttp://www.nanohub.org/home

Physics Reference Data NISThttp://physics.nist.gov/PhysRefData/contents.html 
Rensselaer Institute of Technology Nanotechnology Center

http://www.rpi.edu/research/nanotechnology/index.html

\section{Industrial and Information Engineering}

American Society for Engineering Management : http://www.asem.com/

Canadian Society for Engineering Management : http://www.csem-scgi.ca/

Ewing Marion Kauffman Foundation : http://www.kauffman.org/

Institute of Industrial Engineers: http://www.iienet2.org/

Engineering Management Handbook: http://www.engineering-management.org/publications/em_handbook.html

Engineering Magazine: http://www.engineeringnet.co.uk/

Ideas@ work - web sites for managers:

http://harvardbusinessonline.hbsp.harvard.edu/b01/en/home/index.jhtml

Journal of Industrial Technology: http://nait.org/jit/jit.html

New Zealand management and industrial relations:

http://webdirectory.natlib.govt.nz/dir/en/nz/business-and-economy/management/

Quality Magazine : http://www.qualitymag.com/

\section{Mechanical Engineering}

American Institute of Aeronautics and Astronautics (AIAA): http://www.aiaa.org/

American Society of Mechanical Engineers (ASME) : http://www.asme.org/

Fluid Power Society : http://www.ifps.org/ : http://www.sme.org/

Society of Manufacturing Engineers (SME) : http://www.sme.org/

von Karman Institute for Fluid Dynamics : http://www.vki.ac.be/

A Heat Transfer Textbook : http://web.mit.edu/lienhard/www/ahtt.html

Computational Fluid Dynamic Resources Online : http://www.cfd-online.com/

e-Power and Propulsion : http://www.epower-propulsion.com/

eFluids.com : http://efluids.com/

eFunda: Engineering Fundamentals: http://www.efunda.com/home.cfm

Fluid Power Journal : http://www.fluidpowerjournal.com/

Fluid Power Net International : http://fluid.power.net/

Top Ten Links for Mechanical Engineering : 
An Empirical Study on Design, Development and Accessibility of

Subject Gateway for Engineering Related Subjects

http://www.tenlinks.com/engineering/mechanical/10me.htm

Virtual Album of Fluid Motion : http://www.featflow.de/album/

Wind Tunnels of NASA : http://www.hq.nasa.gov/office/pao/History/SP-440/cover.htm

\section{CONCLUSIONS}

The successful future of subject-gateways on the web is clearly one of the collaborative dynamism ultimately delivering a service, which enables the web access to a comprehensive array of high quality data, and value-added service via a single and unified access point. A coherent and seamless service by a large number of subject gateways is a future ambition, where additional value added features may be included to make subject gate ways a "mature gateways", which will be offering-local document storage and archives; mirrors of remote gateways; reference section or services; large specialized databases in a subject area; full text access to documents; community creating effort such as: discussion list, linkstoexperts, event calendars, news, bookshops, or job indexes, etc.,

In the Information age, everybody talking of information explosion everybody talking about information overload, satisfying user need in simple and easy way has become a challenge for libra and information professional. The subscribing the e resources do not serve the purpose, until and unless the users are informed about them so that such resources are fully utilized. The budget at the disposal of libraries is limited and the demand for information by the researchers is increasing, whereas the time at their disposal is limited. Hence, such portals are important as they are user friendly and provide information through a single window. It is extremely useful for researchers as they can find all the information related to their discipline at one place.

\section{REFERENCES}

1. Dempsey,Lorcan.(2000)“Thesubjectgateway:experiencesandissuesbasedon thee mergence of the Resource Discovery Network", Online information review, vol.24(1),pp.8-23.

2. Koch, Traugott. (2000)“ Quality-controlled subject-gateways: definitions, typologies, empirical overview”, Online information review,vol.24(1),pp.24-34.

3. Gardner, Tracy. and Iannella, Renato. (2000) "Architecture and soft ware solutions", Online information review, vol.24(1),pp.35-39.

4. Heery, Rachel.(2000)“Informationgateways:collaborationoncontent," Online information review, vol. 24(1), pp. 40-45.

5. Hiom,Debra.(2000)"SOCIG:anInternethubforthesocial-sciences,business and law," Online information review, vol. 24 (1 ), pp. 54-58.

6. Place,Emma.(2000)“InternationalcollaborationonInternetSubjectGateways, ”IFLA Journal,vol.26(1),pp.52-56.

7. Hawkins, Donald T. and Levy, Louise R.(1988)“Knowledge Gateways: The Building Blocks," Informationprocessing\&Management,vol.24(4),pp.459-468.

8. Mackie, Morag and Burton, Paul F.(1999)"The use and effectiveness of the eLib subject gateways: a preliminary investigation," Program,vol.33(4),pp.327-337.

9. Janes, Joseph W. and Rosenfeld, Louis B. (1996) "Networked Information Retrieval and Organization: issues and Questions,"JASIS, vol.47(9),pp.711-715.

10. URL: http://www.dlib.org/dlib/december99/12dempsey.html 
11. URL: http://www.dlib.org/dlib/january98/01 kirriemuir.html

12. URL: http://www.ilrt.bris.ac.uk/roads/papers/w4gpospa.html

13. URL: http://www.sosig.ac.uk

14. URL: http://www.desire.org

15. URL: http://www.w3.org

16. URL: http://www.exploit-lib.org/issue3/multilingualgateways/

17. Dempsey, L. and Herry, R.(1998)“Metadata: a current view of practice and issues,” Journal of Documentation, vol.54(2 ), pp.145-172.

18. Kerr, L. and Mac Leod, R. (1997) “EEVL: an Internet gateway for engineers,” Library Hi Tech, vol.15 (3-4), pp. 110-118. 